\title{
PENGARUH FORTIFIKASI NANOPARTIKEL KALSIUM LAKTAT KERABANG TELUR TERHADAP SIFAT KIMIA DAN FISIK BAKSO AYAM
}

\section{THE EFFECT OF EGGSHELL LACTIC CALCIUM NANOPARTICLE FORTIFICATION ON CHEMICAL AND PHYSICAL PROPERTIES OF CHICKEN MEATBALLS}

\author{
Agus Hadi Prayitno*, Edi Suryanto, dan Rusman \\ Fakultas Peternakan, Universitas Gadjah Mada, Yogyakarta, 55281
}

Submitted: 31 December 2014, Accepted: 5 October 2015

\section{INTISARI}

\begin{abstract}
Penelitian ini bertujuan untuk mengetahui pengaruh fortifikasi nanopartikel kalsium laktat kerabang telur terhadap sifat kimia dan fisik bakso ayam. Materi penelitian terdiri atas daging ayam, filler, bumbubumbu, garam, kalsium, dan nanopartikel kalsium laktat kerabang telur. Fortifikasi kalsium dan nanopartikel kalsium laktat kerabang telur pada pembuatan bakso yaitu $0,3 \%$ dari total adonan. Setiap perlakuan terdiri dari lima replikasi. Data hasil uji sifat kimia dan fisik dianalisis dengan analisis variansi rancangan acak lengkap pola searah. Perbedaan rerata diuji dengan uji Duncan's new Multiple Ranges Test. Bakso yang difortifikasi kalsium kerabang telur memiliki kadar air 67,92\% yang lebih rendah, lemak 6,92\% dan abu $2,56 \%$ yang lebih tinggi dibandingkan dengan bakso yang difortifikasi nanopartikel kalsium laktat kerabang telur. Bakso yang difortifikasi kalsium kerabang telur memiliki nilai $\mathrm{pH} 7,34$ dan daya ikat air $58,53 \%$ yang lebih tinggi serta lebih kenyal dibandingkan dengan bakso yang difortifikasi nanopartikel kalsium laktat kerabang telur.
\end{abstract}

(Kata kunci: Bakso ayam, Fortifikasi, Kerabang telur, Nanopartikel kalsium laktat, Sifat kimia dan fisik)

\section{ABSTRACT}

The experiment was conducted to analysis the effect of nanoparticle eggshell calcium lactate fortification on chemical and physical properties of chicken meatballs. The materials were chicken meat, filler, spices, salt, eggshell calcium and nanoparticle calcium lactate. Fortification level of eggshell calcium and nanoparticle calcium lactate on making meatballs was $0.3 \%$ of the total meatball dough. Each treatment consisted of five replications. The data of chemical and physical properties of meatballs were analyzed statistically using variance analysis. The differences between means were tested by Duncan's new Multiple Ranges Test. The meatball fortified with eggshell calcium showed lower moisture content $67.92 \%$, and showed higher fat content $6.92 \%$ and ash $2.56 \%$ than those of nanoparticle eggshell calcium lactate. The meatballs fortified with eggshell calcium had higher $\mathrm{pH}$ value 7.34 and water-holding capacity $58.53 \%$ and more firmness than those of fortified with eggshell calcium lactate.

(Key words: Chemical and physical properties, Chicken meatballs, Eggshell, Fortification, Lactic calcium nanoparticle)

\section{Pendahuluan}

Kulit telur merupakan limbah dari penetasan, rumah tangga dan restoran Phil dan Zhihong, 2009; Amu et al., 2005) dan dapat sangat mudah dikumpulkan dalam jumlah banyak. Kulit telur pembuangan limbah berkontribusi dalam pencemaran lingkungan (Phil dan Zhihong, 2009). Pemanfaatan hasil ikutan dari kerabang telur di Indonesia belum dilakukan secara optimal.

\footnotetext{
* Korespondensi (corresponding author): Telp. +62 8568669898

E-mail: agushp_dgejrot@yahoo.com
}

Direktorat Jenderal Peternakan dan Kesehatan Hewan (2013) menyatakan bahwa produksi telur di Indonesia sampai tahun 2012 mencapai 1.628 .740 ton dan potensi by-product kerabang telur mencapai 179.161 ton per tahun. Kebanyakan Limbah kulit telur dibuang di tempat pembuangan sampah (Stadelman, 2000), sehingga dapat menimbulkan dampak negatif terhadap lingkungan dan kesehatan.

Kandungan kerabang telur $97 \%$ kalsium karbonat (Hunton, 2005) dan dapat dibuat tepung kerabang telur sebagai sumber 
kalsium pangan yaitu sekitar 39\% (Schaafsma et al., 2000). Tepung kerabang telur dapat digunakan sebagai bahan tambahan pangan sumber kalsium (Schaafsma et al., 2000; Ockerman dan Hansen, 2000) sampai level $0,4 \%$ tidak mempengaruhi palatabilitas dan kualitas pemasakan (Ockerman dan Hansen, 2000). Kalsium dari cangkang telur merupakan suplemen yang baik untuk bahan pangan (Hadi, 2005) Kalsium kerabang telur lebih mudah diserap daripada kalsium karbonat komersil dalam usus halus tikus (Omi dan Ezawa, 1998) dan babi (Schaafsma dan Beelen, 1999) yang berfungsi untuk meningkatkan densitas mineral tulang bagi penderita osteoporosis (Schaafsma dan Pakan, 1999; Daengprok et al., 2003) dan dapat menurunkan rasa nyeri (Schaafsma et al., 2000).

Kalsium laktat paling banyak digunakan sebagai fortifikasi kalsium dengan tingkat absorpsi tinggi untuk industri pangan dan obat-obatan (Wang et al., 1999) yang diakui aman dan digunakan sebagai agen penguat, penambah rasa, pengasam, suplemen, pengental (Code of Federal Regulations, Food and Drug Administration, 1997), bahan penstabil (Amu et al., 2005),agen antibakteri (Shelef dan Potluri, 1995). Sebagai bahan pembuatan biomaterial substitusi tulang (Nurlela et al., 2013) serta sebagai agen antitartar pada pasta gigi (Chemaly et al., 1999).

Ukuran nanopartikel yang kecil dapat menyebabkan ekstrak mudah larut dan memiliki efisiensi penyerapan yang tinggi di usus (Poulain dan Nakache, 1998). Beberapa penelitian menunjukkan bahwa penggunaan obat-obatan dalam ukuran nanometer mampu meningkatkan kelarutan dan penyerapan oleh tubuh (Malsch, 2005). Li et al. (2009) dan Wang et al. (2012) melaporkan bahwa melalui metode presipitasi kimia dihasilkan nanopartikel kalsium laktat dengan ukuran partikel 55 sampai $100 \mathrm{~nm}$. Ukuran partikel dari kalsium dan kalsium laktat kerabang telur telah diketahui berukuran 300 dan 75 nm. Kalsium laktat kerabang telur dengan ukuran nano diduga akan lebih mudah larut dan memiliki efisiensi penyerapan yang tinggi di usus.

Pangan yang difortifikasi kalsium berperan penting dalam membantu mencukupi kebutuhan kalsium untuk mengurangi risiko osteoporosis (Weaver, 1998) karena banyak pangan yang defisiensi
(Hanzlik et al., 2005). Asupan berbagai produk pangan yang mengandung kalsium lebih aman daripada mengkonsumsi suplemen kalsium dalam bentuk tablet karena mempengaruhi proses pembentukan dan penyerapan tulang (Niewoehner, 1988). Umumnya, pangan terbaik yang diakui sebagai sumber kalsium yaitu susu dan produk susu tetapi ada sebagian konsumen yang mengalami lactose intolerant (Boyle et al., 1994). Oleh karena itu, perlu sebuah alternatif untuk memenuhi kebutuhan sebagian konsumen melalui fortifikasi kalsium dalam produk daging olahan, seperti bakso.

Bakso merupakan salah satu pangan favorit di Indonesia (Rohman et al., 2011) terbuat dari daging yang terlebih dahulu dihaluskan dan dicampur dengan pati dan bumbu (Purnomo dan Rahardiyan, 2008), dan mempunyai akseptabilitas serta nilai gizi yang cukup tinggi. Produk ini sangat digemari oleh semua lapisan masyarakat Indonesia (Naruki dan Kanoni, 1992). Ion kalsium $\left(\mathrm{Ca}^{2+}\right)$ merupakan kation yang dapat berinteraksi dengan protein daging (Pigott et al., 2000) sehingga dapat mempengaruhi produk daging olahan yang difortifikasi kalsium. Fortifikasi kalsium laktat kerabang telur pada sosis fermentasi dapat memperbaiki kualitas produk sosis (Daengprok et al., 2002). Penelitian ini dilakukan dengan tujuan untuk mengetahui pengaruh fortifikasi kalsium dan nanopartikel kalsium laktat kerabang telur terhadap sifat kimia dan fisik bakso ayam.

\section{Materi dan Metode}

\section{Pembuatan tepung kerabang telur}

Proses pembuatan tepung kerabang telur dilakukan menurut Gongruttananun (2011). Kerabang telur ayam dikumpulkan dari hasil sisa rumah makan. Kerabang telur dibersihkan dari membran kerabang telur dan dicuci menggunakan air. Kerabang telur disterilisasi dengan direbus selama 2 jam kemudian dikeringkan dengan oven pada suhu $95^{\circ} \mathrm{C}$ selama 24 jam. Kerabang telur yang sudah kering kemudian digiling menggunakan blender dan disaring dengan penyaring ukuran 80 mesh sehingga diperoleh tepung kerabang telur.

Pembuatan kalsium oksida kerabang telur

Tepung kerabang telur yang dihasilkan kemudian diproses lanjut menurut Adak dan Purohit (2011). Tepung kerabang telur dipanaskan pada suhu $1.000^{\circ} \mathrm{C}$ selama 2 jam 
untuk proses dekomposisi bahan organik sehingga dihasilkan kalsium oksida kemudian dihaluskan dengan mortar.

\section{Pembuatan nanopartikel kalsium laktat kerabang telur}

Pembuatan nanopartikel kalsium laktat dengan modifikasi metode Wang et al. (2012). Larutan $1 \mathrm{~mol} / \mathrm{L}$ kalsium oksida sebanyak 20 $\mathrm{ml}$ dicampur dengan larutan $6 \mathrm{~mol} / \mathrm{L}$ asam laktat sebanyak $30 \mathrm{ml}$ dengan perbandingan $1: 1,5(\mathrm{v} / \mathrm{v})$ selama 30 menit pada suhu $50^{\circ} \mathrm{C}$ dengan kecepatan $500 \mathrm{rpm} /$ menit menggunakan magnetic stirrer. Etanol 50\% ditambahkan sebanyak $20 \mathrm{ml}(\mathrm{v} / \mathrm{v})$, dioven pada suhu $105^{\circ} \mathrm{C}$ selama 72 jam kemudian dihaluskan menggunakan blender untuk memperoleh bubuk kalsium laktat kerabang telur. Kalsium laktat kerabang telur disimpan untuk digunakan pada proses berikutnya.

\section{Pembuatan bakso}

Daging ayam tanpa tulang dan kulit dibersihkan dari lemak dan jaringan ikat. Daging ayam digiling dengan grinder. Daging ayam giling dicampur dengan $16 \%$ tepung aren, $2 \%$ seasoning, $2 \%$ monosodium glutamat, $1 \%$ merica, $4 \%$ telur, $3 \%$ bawang putih, $3 \%$ bawang merah, $7 \%$ es, dan perlakuan yaitu kontrol $(0 \%)$, kalsium kerabang telur $(0,3 \%)$ dan nanopartikel kalsium laktat kerabang telur $(0,3 \%)$ dari total adonan menggunakan meat processor hingga kalis. Adonan dibentuk bulatanbulatan kemudian direbus dalam air mendidih selama 10 menit. Bakso diangkat dan didinginkan kemudian dilakukan uji karakteristik bakso.

\section{Uji sifat bakso}

Analisis kadar air, protein dan lemak diuji menggunakan near-infrared (NIR) spectroscopy menurut Hervera et al. (2012). Analisis kadar abu dan kalsium diuji menggunakan atomic absorption spectrophotometer (AAS) menurut AOAC (2005). Nilai pH bakso diuji menurut AOAC (2005). Daya ikat air diuji menggunakan modifikasi metode Hamm (1986). Kekenyalan bakso diuji menggunakan penetrometer menurut Candogan dan Kolsarıcı (2003).

Analisis data
Data hasil uji sifat kimia dan fisik
dianalisis dengan analisis variansi
Rancangan Acak Lengkap pola searah.

Perbedaan rerata diuji dengan uji Duncan's new Multiple Ranges Test (Steel dan Torrie, 1993).

\section{Hasil dan Pembahasan}

\section{Sifat kimia bakso}

Sifat kimia bakso yang difortifikasi nanopartikel kalsium laktat kerabang telur disajikan pada Tabel 1.

Kadar air. Hasil penelitian menunjukkan bahwa kadar air dari bakso dengan fortifikasi kalsium dan nanopartikel kalsium laktat kerabang telur berbeda sangat nyata $(P<0,01)$ seperti yang disajikan pada Tabel 1 . Kadar air bakso kontrol, fortifikasi Ca dan CaL yaitu masing-masing 66,79, 67,92, dan $69,59 \%$. Kadar air bakso dengan fortifikasi $\mathrm{Ca}$ dan CaL masih sesuai dengan standar kadar air produk bakso yaitu maksimal $70 \%$ (Standar Nasional Indonesia, 1995). Bakso dengan fortifikasi CaL kerabang telur memiliki kadar air tertinggi yaitu 69,59\% dibandingkan dengan bakso kontrol dan bakso dengan fortifikasi $\mathrm{Ca}$ kerabang telur. Hal ini disebabkan karena CaL dengan ukuran nanopartikel memiliki kelarutan dan kemampuan reaksi yang tinggi (Poulain dan Nakache, 1998; Malsch, 2005) serta ion kalsium $\left(\mathrm{Ca}^{2+}\right)$ merupakan kation yang dapat berinteraksi dengan protein daging (Pigott et al., 2000) sehingga dapat meningkatkan kemampuan bakso untuk mengikat air. Soeparno (2009) menyatakan bahwa kadar air akan sesuai dengan macam lemak dan bahan pengikat yang ada dalam produk daging dan kemampuan mengikat air serta macam protein dan mineral terutama kalsium dan fosfat dalam produk daging.

Kadar lemak. Hasil penelitian menunjukkan bahwa kadar lemak dari bakso dengan fortifikasi kalsium dan nanopartikel kalsium laktat kerabang telur berbeda sangat nyata $(P<0,01)$ seperti yang disajikan pada Tabel 1. Kadar lemak bakso kontrol, fortifikasi Ca dan CaL yaitu masing-masing 6,46, 6,92, dan 6,23\%. Kadar lemak bakso dengan fortifikasi Ca dan CaL melebihi standar kadar lemak untuk produk bakso yaitu maksimal $2 \%$ (Standar Nasional Indonesia, 1995). Hal ini disebabkan karena adanya perbedaan bahan-bahan yang digunakan untuk pembuatan bakso sehingga bakso yang dihasilkan memiliki kadar lemak yang lebih tinggi dibandingkan standar kadar lemak untuk produk bakso. Hal ini diperkuat oleh 
Tabel 1. Rerata kadar air, lemak, protein, abu dan kalsium bakso ayam yang difortifikasi nanopartikel kalsium laktat kerabang telur

(average of moisture, fat, protein, ash and calcium of nanoparticle eggshell lactic calcium fortification to chicken meatballs)

\begin{tabular}{lccc}
\hline \hline \multirow{2}{*}{ Variabel (variable) } & \multicolumn{3}{c}{ Perlakuan (treatment) } \\
\cline { 2 - 4 } & Kontrol (control) (0\%) & Ca $(0,3 \%)$ & CaL $(0,3 \%)$ \\
\hline Kadar air (\%) (moisture (\%)) & $66,79^{\mathrm{a}}$ & $67,92^{\mathrm{b}}$ & $69,59^{\mathrm{c}}$ \\
Kadar lemak (\%) (fat (\%)) & $6,46^{\mathrm{a}}$ & $6,92^{\mathrm{b}}$ & $6,23^{\mathrm{a}}$ \\
Kadar protein (\%) (protein (\%)) & $13,98^{\mathrm{a}}$ & $15,77^{\mathrm{b}}$ & $16,87^{\mathrm{b}}$ \\
Kadar abu (\%) (ash (\%)) & $2,43^{\mathrm{b}}$ & $2,56^{\mathrm{c}}$ & $1,94^{\mathrm{a}}$ \\
Kadar kalsium (\%) (calcium (\%)) & $0,07^{\mathrm{a}}$ & $0,2^{\mathrm{c}}$ & $0,1^{\mathrm{b}}$ \\
\hline $\mathrm{a}, \mathrm{b}, \mathrm{c}$ Superskrip yang berbeda pada baris yang sama menunjukkan perbedaan yang sangat nyata $(\mathrm{P}<0,01)($ different \\
\multicolumn{2}{l}{ superscripts at the same row indicate significant different $(P<0.01))}$.
\end{tabular}

Setiyono (2008) yang menyatakan bahwa kadar lemak tergantung pada kadar lemak daging (macam daging) dan kadar lemak bahan yang ditambahkan dalam produk daging. Selain itu, Edwards (1981) menyatakan bahwa kadar lemak mempunyai hubungan negatif dengan kadar protein.

Kadar protein. Hasil penelitian menunjukkan bahwa kadar protein dari bakso dengan fortifikasi kalsium dan nanopartikel kalsium laktat kerabang telur berbeda sangat nyata $(P<0,01)$ seperti yang disajikan pada Tabel 1. Kadar protein bakso kontrol, fortifikasi $\mathrm{Ca}$ dan $\mathrm{CaL}$ yaitu masing-masing $13,98,15,77$, dan $16,87 \%$. Kadar protein bakso dengan fortifikasi $\mathrm{Ca}$ dan $\mathrm{CaL}$ masih sesuai dengan standar kadar protein produk bakso yaitu minimal 9\% (Standar Nasional Indonesia, 1995). Bakso dengan fortifikasi CaL kerabang telur memiliki kadar protein tertinggi yaitu $16,87 \%$ dibandingkan dengan bakso kontrol dan bakso dengan fortifikasi $\mathrm{Ca}$ kerabang telur. Hal ini disebabkan karena $\mathrm{CaL}$ dengan ukuran nanopartikel memiliki kelarutan dan kemampuan reaksi yang tinggi (Poulain dan Nakache, 1998; Malsch, 2005) serta ion kalsium $\left(\mathrm{Ca}^{2+}\right)$ merupakan kation yang dapat berinteraksi dengan protein daging (Pigott et al., 2000) sehingga dapat meningkatkan proporsi dari protein produk bakso.

Kadar abu. Hasil penelitian menunjukkan bahwa kadar abu dari bakso dengan fortifikasi kalsium dan nanopartikel kalsium laktat kerabang telur berbeda sangat nyata $(P<0,01)$ seperti yang disajikan pada Tabel 1. Kadar abu bakso kontrol, fortifikasi Ca dan CaL yaitu masing-masing 2,43, 2,56, dan $1,94 \%$. Kadar abu bakso dengan fortifikasi $\mathrm{Ca}$ dan $\mathrm{CaL}$ masih sesuai dengan standar kadar abu produk bakso yaitu maksimal 3\% (Standar Nasional Indonesia, 1995). Bakso dengan fortifikasi Ca kerabang telur memiliki kadar abu tertinggi yaitu 2,56\% dibandingkan bakso kontrol dan bakso dengan fortifikasi CaL kerabang telur. Hal ini karena kandungan kalsium Ca kerabang telur lebih tinggi yaitu 50,75\% dibandingkan dengan kandungan kalsium CaL kerabang telur yaitu $6,68 \%$ sehingga kadar abu bakso dengan fortifikasi $\mathrm{Ca}$ kerabang telur paling tinggi dibandingkan dengan bakso kontrol dan bakso dengan fortifikasi CaL kerabang telur. Soeparno (2009) menyatakan bahwa kadar abu untuk daging dan produk daging dipengaruhi oleh bahan organik lain atau bahan lain yang ditambahkan yang mempunyai kadar mineral yang berbeda.

Kadar kalsium. Hasil penelitian menunjukkan bahwa kadar kalsium dari bakso dengan fortifikasi kalsium dan nanopartikel kalsium laktat kerabang telur berbeda sangat nyata $(P<0,01)$ seperti yang disajikan pada Tabel 1. Kadar kalsium bakso kontrol, fortifikasi $\mathrm{Ca}$ dan $\mathrm{CaL}$ yaitu masingmasing $0,07,0,20$, dan $0,10 \%$. Bakso dengan fortifikasi Ca kerabang telur memiliki kadar kalsium tertinggi yaitu 69,59\% dibandingkan dengan bakso kontrol dan bakso dengan fortifikasi CaL kerabang telur. Hal ini disebabkan karena kandungan kalsium dari Ca kerabang telur lebih tinggi yaitu 50,75\% dibandingkan dengan kandungan kalsium CaL kerabang telur yaitu $6,68 \%$ sehingga kalsium produk bakso dengan fortifikasi $\mathrm{Ca}$ kerabang telur paling tinggi dibandingkan dengan bakso kontrol dan bakso dengan fortifikasi CaL kerabang telur.

\section{Sifat fisik bakso}

Sifat fisik bakso yang difortifikasi nanopartikel kalsium laktat kerabang telur disajikan pada Tabel 2.

Nilai pH. Hasil penelitian menunjukkan bahwa nilai $\mathrm{pH}$ dari bakso dengan fortifikasi kalsium dan nanopartikel kalsium laktat kerabang telur berbeda sangat nyata $(P<0,01)$ seperti yang disajikan pada Tabel 2 . 
Tabel 2. Rerata nilai $\mathrm{pH}$, daya ikat air dan kekenyalan bakso ayam yang difortifikasi nanopartikel kalsium laktat kerabang telur

(average of value of $\mathrm{pH}$, water holding capacity and firmness of of nanoparticle eggshell calcium lactate fortification to chicken meatballs)

\begin{tabular}{lccc}
\hline \hline \multirow{2}{*}{ Variabel (variable) } & \multicolumn{3}{c}{ Perlakuan (treatment) } \\
\cline { 2 - 4 } & Kontrol (control) $(0 \%)$ & Ca $(0,3 \%)$ & CaL $(0,3 \%)$ \\
\hline Nilai $\mathrm{pH}$ (value of $\mathrm{pH})$ & $6,14^{\mathrm{b}}$ & $7,34^{\mathrm{c}}$ & $5,84^{\mathrm{a}}$ \\
Daya ikat air (\%) (water holding capacity $(\%))$ & $57,64^{\mathrm{b}}$ & $58,53^{\mathrm{b}}$ & $48,18^{\mathrm{a}}$ \\
Kekenyalan (mm/45 g) (firmness $(\mathrm{mm} / 45 \mathrm{~g}))$ & $6,44^{\mathrm{b}}$ & $1,80^{\mathrm{a}}$ & $16,98^{\mathrm{c}}$ \\
\hline a,b,c Superskrip yang berbeda pada baris yang sama menunjukkan perbedaan yang sangat nyata $(\mathrm{P}<0,01)($ different \\
superscripts at the same row indicate significant different $(P<0.01))$.
\end{tabular}

Nilai $\mathrm{pH}$ bakso kontrol, fortifikasi $\mathrm{Ca}$ dan CaL yaitu masing-masing 6,14, 7,34, dan 5,84 . Bakso dengan fortifikasi CaL kerabang telur memiliki nilai $\mathrm{pH}$ bakso terendah yaitu 5,84 dibandingkan bakso kontrol dan bakso dengan fortifikasi Ca kerabang telur. Hal ini dikarenakan CaL kerabang telur memiliki keasaman yang lebih rendah. CaL terbentuk dari reaksi antara $\mathrm{Ca}$ dan asam laktat sehingga $\mathrm{CaL}$ kerabang telur yang difortifikasikan ke produk bakso dapat menurunkan nilai $\mathrm{pH}$ bakso tersebut. Kalsium kerabang telur yang difortifikasi pada bakso yaitu dalam bentuk $\mathrm{CaO}$ terurai menjadi $\mathrm{Ca}^{2+}$ dan $\mathrm{O}^{2-}$. $\mathrm{Ca}^{2+}$ bersifat basa dan $\mathrm{O}^{2-}$ bersifat asam sehingga oksigen akan menguap sebagai gas dan bakso yang ada mempunyai kadar kalsium yang bersifat basa menyebabkan nilai $\mathrm{pH}$ bakso naik. Ion kalsium $\left(\mathrm{Ca}^{2+}\right)$ merupakan kation yang dapat berinteraksi dengan protein daging (Pigott et al., 2000). Peningkatan $\mathrm{pH}$ ultimate daging, pada umumnya meningkatkan keempukan dan juga meningkatkan DIA. Buckle et al. (1985) menyatakan bahwa nilai $\mathrm{pH}$ daging yang rendah dapat mengakibatkan struktur daging terbuka sehingga menurunkan daya ikat air, sedangkan nilai $\mathrm{pH}$ yang tinggi dapat mengakibatkan struktur daging tertutup sehingga meningkatkan daya ikat air.

Daya ikat air. Hasil penelitian menunjukkan bahwa daya ikat air dari bakso dengan fortifikasi kalsium dan nanopartikel kalsium laktat kerabang telur berbeda sangat nyata $(P<0,01)$ seperti yang disajikan pada Tabel 2. Daya ikat air bakso kontrol, fortifikasi Ca dan CaL yaitu masing-masing 57,64, 58,53 , dan $48,18 \%$. Besarnya penurunan nilai $\mathrm{pH}$ akan mempengaruhi daya ikat air. Nilai $\mathrm{pH}$ normal daging yaitu sekitar 5,5 yang merupakan titik isoelektrik dari protein daging. Pengolahan atau pengawetan dengan asamasam organik seperti cuka dan rempahrempah dapat meningkatkan daya ikat air dari protein daging pada kondisi asam dari titik isoelektrik (Lawrie, 2003). Soeparno (2009) menyatakan bahwa pada daging yang pHnya lebih rendah (sekitar 6,0), biasanya mengandung jus yang lebih banyak.

Daya ikat air dipengaruhi oleh $\mathrm{pH}$ daging (Alvarado dan McKee, 2007). Bakso dengan fortifikasi Ca kerabang telur memiliki daya ikat air tertinggi yaitu $58,53 \%$ dibandingkan dengan bakso kontrol dan bakso dengan fortifikasi CaL kerabang telur. Hal ini dikarenakan bakso dengan $\mathrm{Ca}$ kerabang telur memiliki nilai $\mathrm{pH}$ yang tinggi yaitu 7,34 dibandingkan dengan bakso kontrol dan bakso dengan fortifikasi CaL kerabang telur, tingginya DIA ini diduga karena tingginya nilai $\mathrm{pH}$ yang mengakibatkan struktur daging tertutup sehingga daya ikat air tinggi (Buckle et al., 1985; Bouton et al., 1971). Pearson dan Young (1989) menyatakan bahwa daya ikat air akan meningkat jika nilai $\mathrm{pH}$ meningkat. Bouton et al. (1972) menyatakan bahwa nilai $\mathrm{pH}$ berhubungan dengan nilai DIA, air yang tertahan di dalam otot meningkat sejalan dengan naiknya $\mathrm{pH}$, walaupun kenaikannya kecil. Pada $\mathrm{pH}$ yang lebih tinggi dari $\mathrm{pH}$ isoelektrik protein daging, sejumlah muatan positif dibebaskan dan terdapat surplus muatan negatif yang mengakibatkan penolakan dari miofilamen dan memberi banyak ruang untuk molekul air sehingga daya ikat air bakso menjadi meningkat (Soeparno, 2009) dan kemampuan menahan air merupakan faktor mutu yang penting dan hal ini diperbaiki oleh nilai $\mathrm{pH}$ yang tinggi (Buckle et al., 1985).

Bakso dengan fortifikasi CaL kerabang telur memiliki daya ikat air terendah yaitu $48,18 \%$ yang dipengaruhi oleh $\mathrm{pH}$ bakso yang rendah yaitu 5,48 , rendahnya nilai $\mathrm{pH}$ yang mengakibatkan struktur daging terbuka sehingga menurunkan daya ikat air (Buckle et al., 1985) seperti halnya pada periode 
pembentukan asam lakat menyebabkan penurunan $\mathrm{pH}$ otot postmortem, menurunkan daya ikat iar daging dan banyak air yang berasosiasi dengan protein otot akan bebas keluar dari serabut otot (Soeparno, 2009). Selain itu, karena protein sarkoplasma dari otot sangat mudah rusak dalam suasana asam dan cenderung untuk kehilangan daya ikat airnya pada pH di bawah 6,2 (Buckle et al., 1985).

Kekenyalan. Hasil penelitian menunjukkan bahwa kekenyalan dari bakso dengan fortifikasi kalsium dan nanopartikel kalsium laktat kerabang telur berbeda sangat nyata $(P<0,01)$ seperti yang disajikan pada Tabel 2. Kekenyalan bakso kontrol, fortifikasi Ca dan CaL yaitu masing-masing 6,44, 1,80, dan 16,98 mm/45 g. Bakso dengan fortifikasi Ca kerabang telur memiliki tingkat kekenyalan paling kenyal yaitu 1,80 $\mathrm{mm} / 45 \mathrm{~g}$ dibandingkan dengan bakso kontrol dan bakso dengan fortifikasi CaL kerabang telur. Hal ini dikarenakan kekenyalan bakso yang forfikasi $\mathrm{Ca}$ kerabang telur dipengaruhi ion kalsium $\left(\mathrm{Ca}^{2+}\right)$ yang merupakan kation yang dapat berinteraksi dengan protein daging (Pigott et al., 2000) sehingga dapat meningkatkan kekenyalan bakso. Selain itu, bakso dengan fortifikasi Ca kerabang memiliki daya ikat air yang paling tinggi yaitu 58,53\% yang dipengaruhi oleh nilai $\mathrm{pH}$ bakso sehingga kemampuan untuk mengikat air meningkat. Soeparno (2009) menyatakan bahwa peningkatan $\mathrm{pH}$ ultimate daging pada umumnya dapat meningkatkan keempukan daging. Selain itu, daging dengan $\mathrm{pH}$ tinggi mempunyai keempukan yang lebih tingi daripada daging dengan $\mathrm{pH}$ rendah (Bouton et al., 1971).

\section{Kesimpulan}

Bakso yang difortifikasi kalsium kerabang telur memiliki kadar air 67,92\% yang lebih rendah, lemak $6,92 \%$ dan abu $2,56 \%$ yang lebih tinggi dibandingkan dengan bakso yang difortifikasi nanopartikel kalsium laktat kerabang telur. Bakso yang difortifikasi kalsium kerabang telur memiliki nilai $\mathrm{pH} 7,34$ dan daya ikat air 58,53\% yang lebih tinggi serta lebih kenyal dibandingkan dengan bakso yang difortifikasi nanopartikel kalsium laktat kerabang telur.

\section{Ucapan Terima Kasih}

Ucapan terima kasih disampaikan kepada Fakultas Peternakan UGM Yogyakarta atas pemberian dana Hibah Penelitian Pascasarjana Fakultas Peternakan UGM Tahun Anggaran 2013.

\section{Daftar Pustaka}

Adak, M. D. and K. M. Purohit. 2011. Synthesis of nano-crystalline hydroxyapatite from dead snail shells for biological implantation. Trends Biomater. Artif. Organs. 25: 101-106.

Alvarado, C. and S. McKee. 2007. Marination to improve functional properties and safety of poultry meat. J. Appl. Poult. Res. 16: 113-120.

Amu, O. O., A. B. Fajobi and B. O. Oke. 2005. Effect of eggshell powder on the stabilizing potential on lime on an expansive clay soil. J. Applied Sci. 5: 1474-1478.

AOAC. 2005. Official Methods of Analysis of the Association of Analytical Chemist. $18^{\text {th }}$ edn. Association of Official Analytical Chemist, Washington DC.

Bouton, P. E., P. V. Harris and W. R. Shorthose. 1971. Effect of ultimate $\mathrm{pH}$ upon the water-holding capacity and tenderness of mutton. J. Food Sci. 36: 435-439.

Bouton, P. E., P. V. Harris and W. R. Shorthose. 1972. The effect of ultimate $\mathrm{pH}$ on ovine muscle: water holding capacity. J. Food. Sci. 37: 351-355.

Boyle, E. A. E., P. B. Addis and R. J. Epley. 1994. Calcium fortified, reduced fat beef emulsion product. J. Food Sci. 59: 928-932.

Buckle, K. A., R. A. Edwards, G. H. Fleet and M. Wooton. 1985. Ilmu Pangan. Diterjemahkan oleh Purnomo, $\mathrm{H}$ dan Adiono. Cetakan Ke-1. UI Press, Jakarta.

Candogan, K. and N. Kolsarici. 2003. The effects of carrageenan and pectin on some quality characteristics of low - fat beef frankfurters. Meat Sci. 64: 199203.

Chemaly, Z., H. Muhr and M. Fick. 1999. Crystallization kinetics of calcium lactate in a mixed-suspension-mixedproduct removal crystallizer. Ind. Eng. Chem. Res. 38: 2803-2808. 
Code of Federal Regulations, Food and Drug Administration. 1997. Calcium lactate; Title 21, 184.1207. US Government Printing Office, Washington, DC.

Daengprok, W., W. Garnjanagoonchorna and Y. Mine. 2002. Fermented pork sausage fortified with commercial or hen eggshell calcium lactate. Meat Sci. 62: 199-204.

Daengprok, W., W. Garnjanagoonchorn, O. Naivikul, P. Pornsinlpatip, K. Issigonis, and Y. Mine. 2003. Chicken eggshell matrix proteins enhance calcium transport in the human intestinal epithelial cells, Caco-2. J. Agric. Food Chem. 51: 6056-6061.

Direktorat Jenderal Peternakan dan Kesehatan Hewan. 2013. Statistik Peternakan dan Kesheatan Hewan 2013. Direktorat Jenderal Peternakan dan Kesehatan Hewan Kementerian Pertanian RI, Jakarta.

Edwards, H. M. Jr. 1981. Carcass composition studies. 3. Influence of age, sex and calorie protein contents of the diet on carcass composition of Japanese quail. J. Poult. Sci. 60: 25062512.

Gongruttananun, H. 2011. Effects of eggshell calcium on productive performance, plasma calcium, bone mineralization, and gonadal characteristics in laying hens. Poult. Sci. 90: 524-529.

Hadi, W. S. 2005. Sifat fisik dan organoleptik minuman instan madu bubuk dengan penambahan efek effervescent dari tepung kerabang telur. Skripsi, Institut Pertanian Bogor, Bogor.

Hamm, R. 1986. Functional properties of the myofibrillar system and their measurement. In: Muscle as Food. Bechtel, P. J. (ed). Academic Press, New York. pp. 135-199.

Hanzlik, R. P., S. C. Fowler and D. H. Fisher. 2005. Relative bioavailability of calcium from calcium formate, calcium citrate, and calcium carbonate. J. Pharmacol. Exp. Ther. 313: 1217-1222.

Hervera, M., C. Castrillo, E. Albanell and M. D. Baucells. 2012. Use of near-infrared spectroscopy to predict energy content of commercial dog food. J. Anim. Sci. 90: 4401-4407.

Hunton, P. 2005. Research on eggshell structure and quality: An historical overview. Braz. J. Poult. Sci. 7: 67-71.
Lawrie, R. A. 2003. Ilmu Daging. Edisi Ke-5. Penerjemah: Parakkasi, A. Universitas Indonesia Press, Jakarta.

Li, Z., Y. Zhang and T. Tan. 2009. Preparation of edible nano calcium lactate crystal from crude L-lactic acid via chemical precipitation method. J. Biosci. Bioeng. 108: S138.

Malsch, N. H. 2005. Biomedical Nanotechnology. CRC Press, Boca Raton.

Naruki, S. dan S. Kanoni. 1992. Kimia dan Teknologi Pengolahan Hasil Hewani. Pusat Antar Universitas Pangan dan Gizi, Universitas Gadjah Mada, Yogyakarta.

Niewoehner, C. 1988. Calcium and osteoporosis. Cereal Foods World 33: 784-787.

Nurlela, A., S. U. Dewi, K. Dahlan, dan D. S. Soejoko. 2013. Pemanfaatan limbah cangkang telur ayam dan bebek sebagai sumber kalsium untuk sintesis mineral tulang. Jurnal Pendidikan Fisika Indonesia 10: 81-85.

Ockerman, H. W. and C. L. Hansen. 2000. Animal By-Product Processing and Utilization. CRC Press, Boca Raton.

Omi, N. and I. Ezawa. 1998. Effect of eggshell $\mathrm{Ca}$ on preventing of bone loss after ovariectomy. J. Home Econ. Jpn. 49: 277-282.

Pearson, A. M. and R. B. Young. 1989. Meat and Biochemistry. Academy Press Inc., California.

Phil, G. and M. Zhihong. 2009. High value products from hatchery waste. RIRDC publication no. 09/061. preparations. glatz.phil@saugov.sa.gov.au.

Pigott, R. S., P. B. Kenney, S. Slider and M. K. Head. 2000. Formulation protocol and dicationic salts affect protein functionality of model system beef batters. J. Food Sci. 65: 1151-1154.

Poulain, N. and E. Nakache. 1998. Nanoparticles from vesicles polymerization. II. Evaluation of their encapsulation capacity. J. Polym. Sci. 36: 3035-3043.

Purnomo, H. and D. Rahardiyan. 2008. Review Article: Indonesian traditional meatball. Int. Food Res. J. 15: 101-108. 
Rohman, A., Sismindari, Y. Erwanto and Y. B. C. Man. 2011. Analysis of pork adulteration in beef meatball using Fourier transform infrared (FTIR) spectroscopy. Meat Sci. 88: 91-95.

Schaafsma, A. and I. Pakan. 1999. Short-term effects of a chicken egg shell powder enriched dairy-based products on bone mineral density in persons with osteoporosis or osteopenia. Bratisl. Lek. Listy. 100: 651-656.

Schaafsma, A. and G. M. Beelen. 1999. Eggshell powder, a comparable or better source of calcium than purified calcium carbonate: piglet studies. J. Sci. Food Agric. 79: 1596-1600.

Schaafsma, A., I. Pakan, G. J. H. Hofstede, F. A. J. Muskiet, E. Van Der Veer and P. J. F. De Vries. 2000. Mineral, amino acid, and hormonal composition of chicken eggshell powder and the evaluation of its use in human nutrition. Poult. Sci. 79: 1833-1838.

Setiyono. 2008. Rekstrukturisasi Daging Sapi untuk Pangan Kesehatan : Studi pada Ratus Norvegicus L. Disertasi. Program Studi Ilmu dan Industri Peternakan, Sekolah Pascasarjana Universitas Gadjah Mada, Yogyakarta.

Shelef, L. A. and V. Potluri. 1995. Behaviour of foodborne pathogens in cooked liver sausage containing lactates. Food Microbiol. 12: 221-227.
Soeparno. 2009. IImu dan Teknologi Daging. Cetakan Ke-5. Gadjah Mada Press, Yogyakarta.

Stadelman, W. J. 2000. Eggs and Egg Products: Encyclopedia of Food Science and Technology John Wiley \& Sons, New York. pp. 593-599.

Standar Nasional Indonesia. 1995. Bakso Daging Sapi. (SNI 01-3818-1995). Badan Standardisasi Nasional, Jakarta.

Steel, R. G. D. dan J. H. Torrie. 1993. Prinsip dan Prosedur Statistik. Suatu Pendekatan Biometrik. Diterjemahkan oleh M. Syah. PT Gramedia Pustaka Utama, Jakarta.

Wang, L., I. Sondi and E. Matijević. 1999. Preparation of uniform needle-like aragonite particles by homogeneous precipitation. J. Colloid Interface Sci. 218: 545-553.

Wang, Y., L. Huang and J. Wu. 2012. Optimization of conditions for calcium lactate nano-particle production. Adv. Materials Res. 479: 314-317.

Weaver, C. 1998. Calcium in food fortification strategies. Int. Dairy J. 8: 443-449. 